\title{
Serum Biochemical Study to Cattle-calves naturally infected with Theileria annulata Confirmed by Nested Polymerase Chain Reaction in Bikaner District of Rajasthan, India
}

\author{
Pavan Goyal*, Anju Chahar, R.K. Tanwar, Fakhruddin and S.S. Soni
}

Department of Epidemiology and Preventive Veterinary Medicine, College of Veterinary and Animal Science, Rajasthan University of Veterinary and Animal Sciences, Bikaner-334 001, Rajasthan, India

*Corresponding author

\section{A B S T R A C T}

\begin{tabular}{|l|}
\hline Ke y w o r d s \\
Cattle-calves, Serum, \\
nPCR, SGOT, SGPT, \\
$\begin{array}{l}\text { DNA, Theileria } \\
\text { annulata, Prevalence }\end{array}$ \\
\hline Article Info \\
\hline $\begin{array}{l}\text { Accepted: } \\
\text { 26 January } 2018 \\
\text { Available Online: } \\
\text { 10 February } 2018\end{array}$ \\
\hline \hline
\end{tabular}

A total of 100 cattle-calves irrespective of their age, sex and breed brought to Teaching Veterinary Clinical Complex of College of Veterinary and Animal science, Bikaner for treatment were screened for Theileria annulata infection. Blood samples were collected from jugular vein aseptically in vacutainers with and without anticoagulant for genomic DNA and serum isolation, respectively. The entire isolated DNA samples were subjected to nested polymerase chain reaction (nPCR), out of which 41 samples were found positive for Theileria annulata infection. All the serum samples were analyzed by using IDEXX vet test TM kit as per standard procedure. Serum biochemical analyses revealed statistically highly significant $(\mathrm{P}<0.01)$ decrease in Mean \pm SE values of serum albumin and albumin-globulin ratio while non-significant $(\mathrm{P}>0.05)$ decrease in total protein and serum calcium; significant $(\mathrm{P}<0.05)$ decrease in serum glucose; significant $(\mathrm{P}<0.05)$ increase in serum alkaline phosphatase and SGOT while non-significant $(\mathrm{P}>0.05)$ increase in Blood urea nitrogen, serum creatinine, SGPT and serum globulin levels in nPCR positive cattle-calves as compared to nPCR negative cattle-calves.

\section{Introduction}

Bovine tropical theileriosis is a protozoan disease caused by blood protozoa Theileria annulata and it is transmitted by tick Hyalomma anatolicum anatolicum. It causes significant economic losses in large parts of Asia (Hasanpour et al., 2013). It is mainly seen in cattle, sheep and goat as well as in wild and captive ungulates (Radostits et al., 2007). This intracellular infection inflicts economic burden on cattle breeders in terms of mortality and morbidity as well as expenses spent on prophylactic measures against disease and treatment (Durrani et al., 2008).

Theileria spp. infection can cause acute, subacute or chronic disease pathology (Gill et al., 1977). In T. annulata infection, the most common clinical symptoms are weakness, weight loss, anorexia, high body temperature, petechia on the conjunctival mucosa, swollen lymph nodes, anaemia and cough. On later stages of theileriosis, infected animals cannot 
stand up, their body temperatures are under normal values $\left(<38.5^{\circ} \mathrm{C}\right)$, icterus, dehydration and blood in faeces are the occasional clinical symptoms (Bakheit et al., 2004; Radostits et al., 2007). Calves ( $\leq 4$ months of age) infected with Theileria annulata suffered from emaciation, anaemia, unilateral or bilateral exophthalmia, petechiae in conjunctiva, oral and nasal mucosa, and occasionally in the pinnae. Widespread subcutaneous nodules with 0.5 to $3.0 \mathrm{~cm}$ diameter are also detected, as well as enlarged superficial lymph nodes, particularly the submandibular, the retropharyngeal and sometimes the prescapular (Branco et al., 2010).

Haemato-biochemical examination reveals significant $(\mathrm{P} \leq 0.05) \quad$ decrease in total erythrocyte count, packed cell volume, haemoglobin, serum total proteins, albumin, globulins, glucose, calcium, phosphorus, cholesterol and triglycerides concentrations in cattle affected with bovine theileriosis compared with healthy controls, while significant $(\mathrm{P} \leq 0.05) \quad$ increase in serum bilirubin and alanine aminotransferase of affected cattle compared with healthy controls (Khan et al., 2011).

\section{Materials and Methods}

A total of 100 cattle-calves irrespective of their age, sex and breed brought to Teaching Veterinary Clinical Complex of College of Veterinary and Animal science, Bikaner for treatment were screened for Theileria annulata infection. Blood samples were collected from jugular vein aseptically in vacutainers with and without anticoagulant for genomic DNA and serum isolation, respectively. The entire isolated DNA samples were subjected to nested polymerase chain reaction (nPCR) using primers sets reported by D'Oliveira et al., (1995). All the serum samples were analyzed by using IDEXX vet test TM kit as per standard procedure.

\section{Results and Discussion}

Mean \pm SE values along with range of serum biochemical parameters of nPCR positive and negative cattle-calves are presented in Table 1 and Figure 1.

There was significant $(\mathrm{P}<0.05)$ decreased in serum glucose level in nPCR positive cattlecalves as compared to nPCR negative cattlecalves. Similar findings have been reported by Yadav and Sharma (1986), Col and Uslu (2007), Hussein et al., (2007), Kizil et al., (2007), Khan et al., (2011) and Kumar (2012). There was non-significant $(\mathrm{P}>0.05)$ increased in blood urea nitrogen and serum creatinine in nPCR positive cattle-calves as compared to nPCR negative cattle-calves. Similar findings have also been reported by Omer et al., (2003), Ugalmugle et al., (2010) and Modi et al., (2015).

There was significant $(\mathrm{P}<0.05)$ increased in SGOT while non-significant $(\mathrm{P}>0.05)$ increased in SGPT levels in nPCR positive cattle-calves as compared to nPCR negative cattle-calves. Similar findings have also been reported by Laiblin et al., (1978) and Col and Uslu (2007).

There was significant $(\mathrm{P}<0.05)$ increased in serum alkaline phosphatase level in nPCR positive cattle-calves as compared to nPCR negative cattle-calves. Similar findings were also reported by Yadav and Sharma (1986), Sharma et al., (1987), Sandhu et al., (1998), Singh et al., (2001), Alam and Nasr (2011) and Dede et al., (2014).

There was non-significant $(\mathrm{P}>0.05)$ decreased in serum total protein and non-significant increased in serum globulin while highly significant $(\mathrm{P}<0.01)$ decrease in serum albumin and albumin-globulin ratio in nPCR positive cattle-calves as compared to nPCR negative cattle-calves. 
Table.1 Mean \pm SE values along with range of serum biochemical parameters of nPCR positive and negative cattle-calves

\begin{tabular}{|c|c|c|c|c|c|}
\hline \multirow{2}{*}{$\begin{array}{l}\text { S. } \\
\text { No. }\end{array}$} & \multirow[b]{2}{*}{ Parameters } & \multicolumn{2}{|c|}{ Mean \pm SE } & \multicolumn{2}{|c|}{ Range } \\
\hline & & $\begin{array}{l}\text { nPCR positive } \\
\text { cattle-calves }\end{array}$ & $\begin{array}{l}\text { nPCR negative } \\
\text { cattle-calves }\end{array}$ & $\begin{array}{l}\text { nPCR positive } \\
\text { cattle-calves }\end{array}$ & $\begin{array}{l}\text { nPCR negative } \\
\text { cattle-calves }\end{array}$ \\
\hline 1 & $\begin{array}{l}\text { Serum Glucose* } \\
(\mathrm{mg} / \mathrm{dl})\end{array}$ & $57.34 \pm 0.97^{\mathrm{a}}$ & $71.22 \pm 0.86^{\mathrm{b}}$ & $15-151$ & $20-160$ \\
\hline 2 & BUN (mg/dl) (ns) & $25.36 \pm 0.71$ & $25 \pm 0.55$ & $2-123$ & $3-58$ \\
\hline 3 & $\begin{array}{l}\text { Serum Creatinine } \\
(\mathrm{mg} / \mathrm{dl})(\mathrm{ns})\end{array}$ & $1.35 \pm 0.18$ & $1.29 \pm 0.14$ & $0.4-8.2$ & $0.2-3.7$ \\
\hline 4 & $\begin{array}{l}\text { SGOT* } \\
(\mathrm{IU} / \mathrm{L})\end{array}$ & $116.66 \pm 1.47^{b}$ & $80.49 \pm 0.92^{a}$ & $18-328$ & $25-194$ \\
\hline 5 & $\begin{array}{l}\text { SGPT (IU/L) } \\
(\mathrm{ns})\end{array}$ & $39.02 \pm 0.64$ & $37.58 \pm 0.65$ & $10-100$ & $10-77$ \\
\hline 6 & $\mathrm{TP}(\mathrm{g} / \mathrm{dl})(\mathrm{ns})$ & $5.99 \pm 0.19$ & $6.49 \pm 0.20$ & $3-12$ & $3.3-9.4$ \\
\hline 7 & Albumin** (g/dl) & $2.58 \pm 0.14^{\mathrm{a}}$ & $3.42 \pm 0.15^{b}$ & $1.3-6$ & $1.7-5$ \\
\hline 8 & Globulin (g/dl) (ns) & $3.42 \pm 0.15$ & $3.07 \pm 0.15$ & $1.1-6$ & $1.5-4.9$ \\
\hline 9 & $\mathrm{~A} / \mathrm{G}$ ratio** & $0.79 \pm 0.08^{a}$ & $1.15 \pm 0.09^{b}$ & $0.43-1.82$ & $0.69-2.39$ \\
\hline 10 & ALKP* (IU/L) & $155.12 \pm 1.91^{b}$ & $102.19 \pm 1.51^{\mathrm{a}}$ & $10-554$ & $13-453$ \\
\hline 11 & $\mathrm{Ca}(\mathrm{mg} / \mathrm{dl})(\mathrm{ns})$ & $8.45 \pm 0.24$ & $8.53 \pm 0.21$ & $3-13$ & $3.9-12.1$ \\
\hline
\end{tabular}

(Means with different superscripted letters in the same row differ significantly) ns $(\mathrm{P}>0.05)=$ non-significant $*(\mathrm{P}<0.05)=$ statistically significant,

$* *(\mathrm{P}<0.01)=$ highly significant

Fig.1 Bar diagram showing mean values of serum biochemical parameters of nPCR positive and negative cattle-calves

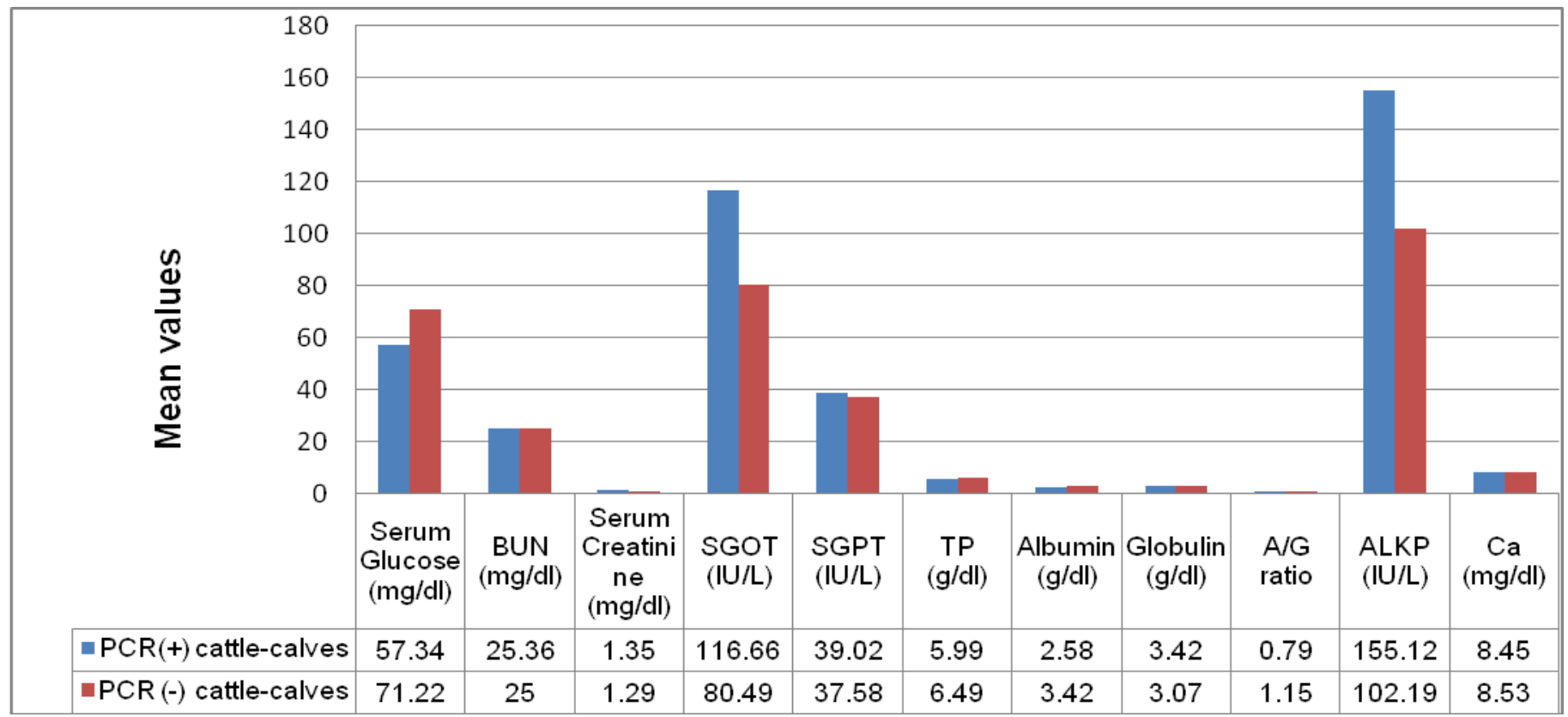


Similar findings were also reported by Dimopoullos (1970), Coles (1986), Behnke et al., (1992), Turgut (2000), Singh et al., (2001), Col and Uslu (2007) and Hussein et al., (2007).

There was non-significant $(\mathrm{P}>0.05)$ decreased in serum calcium level in nPCR positive cattle-calves as compared to nPCR negative cattle-calves. Similar findings were also reported by Dhar and Gautam (1977) and Sandhu et al., (1998).

Decrease in serum glucose level may be due to utilization of glucose by Theileria in the blood and hepatic dysfunction as a result of Theileria infection (Col and Uslu, 2007) or may result from persistent fever due to the disease and inappetence developed by the severity of disease (Yadav and Sharma, 1986; Hussein et al., 2007 and Kizil et al., 2007).

Increase in SGOT level may be due to hepatic tissue damage that includes coagulation necrosis, distortion of hepatic cords with heavy infiltration of lymphocytes in the periportal areas indicating severe damage to hepato-biliary system due to hypoxia resulting from anaemia and jaundice (Col and Uslu, 2007).

Increase in serum ALKP activity in infected animals indicates hepatic tissue damage including coagulative necrosis, distortion of hepatic cords and heavy infiltration of the hepatic tissues with lymphocytes. This further indicated the consequences of hypoxia resulting from anaemia and jaundice (Sandhu et al., 1998).

Hypoalbuminemia may result from increase in albumin excretion (dense albuminuria) due to renal failure, synthesis impairment and/or extensive protein degradation during prolonged fever (Dimopoullos, 1970) or may be due to liver failure (Singh et al., 2001) or due to extravascular accumulation of proteinaceous fluids, resulting from diseased lymph nodes, and thus explained the oedema and body cavity effusions (Col and Uslu, 2007) or due to harmful effect of toxic metabolites of Theileria spp. on liver cells (Hussein et al., 2007).

Decrease in serum calcium level may be due to the fact that animals are young and feed on whole milk, even in a state of recumbency (Sandhu et al., 1998).

Bovine tropical theileriosis is a burning veterinary problem of the rural livestock oriented communities. It has profound effect on serum biochemical parameters and causes huge morbidity and mortality in cattle population, which reflects economic losses and elevates the poverty level.

\section{Acknowledgements}

The authors are highly thankful to the Dean, CVAS, Bikaner; Dr. B.N. Shringi, Professor, Department of Microbiology and Biotechnology and Dr. G.C. Gahlot, Professor and Head, Department of Animal Genetics and Breeding, College of Veterinary and Animal Science, Bikaner, Rajasthan for providing necessary facilities to carry out the present investigation. This study is financially supported by the Rajasthan University of Veterinary and Animal Sciences, Bikaner, Rajasthan.

\section{References}

Alam, T.H. and Nasr, S.M. 2011. Haematological and biochemical investigation in bovine babesiosis and theileriosis. Benha Veterinary Medical Journal. 22(2): 118-126.

Bakheit, M.A., Schnittger, J., Salih, D.A., Boguslawski, K., Beyer, D., Fadl, M. and Ahmed, J.S. 2004. Application of 
the recombinant Theileria annulata surface protein in an indirect ELISA for the diagnosis of tropical theileriosis. Parasitol. Res. 92: 299-302.

Behnke, J.M., Barnard, C.J. and Wakelin, D. 1992. Understanding chronic nematode infections: Evolutionary considerations, current hypotheses and the way forward. Int. J. Parasitol. 22: 861-907.

Branco, S., Orvalho, J., Leitao, A., Pereira, I., Malta, M., Mariano, I., Carvalho, T., Baptista, R., Shiels, B.R. and Peleteiro, M.C. 2010. Fatal cases of Theileria annulata infection in calves in Portugal associated with neoplastic-like lymphoid cell proliferation. Journal of Veterinary Science. 11(1): 27-34.

Col, R. and Uslu, U. 2007. Changes in selected serum components in cattle naturally infected with Theileria annulata. Bull. Vet. Inst. Pulawy. 51: 15-18.

Coles, E.H. 1986. Veterinary Clinical Pathology, fourth ed. Saunders Company Philadelphia, USA, pp. 135.

D’Oliveira, C., Vandermerve, M., Habela, M., Jacquiet, P. and Jongejan, F. 1995. Detection of Theileria annulata in blood samples of carrier cattle by PCR. J. Clin. Microbiol. 33(10): 2665-2669.

Dede, S., Altug, N., Deger, Y., Ozdal, Y. and Ceylan, E. 2014. Serum biochemical profile and protein fractions in cattle with Theileriosis. Revue Med. Vet. 165: 5-6, 137-143.

Dhar, S. and Gautam, O.P. 1977. Some biochemical aspects of Theileria annulata infection of cattle. Indian J. of Animal Sci. 47: 169-172.

Dimopoullos, G.T. 1970. Plasma proteins in clinical biochemistry of domestic animals, Kaneko J. J., Cornelius C. E. (eds), second ed. Academic Press, New York, London, Vol. 1., pp. 97-129.

Durrani, A.Z., Shakoori, A.R. and Kamal, N. 2008. Bionomics of Hyalomma ticks in three districts of Punjab. Pakistan J. Anim. Plant Sci. 18(1): 20-23.

Gill, B.S., Bhattacharyulu, Y. and Kaur, D. 1977. Symptoms and pathology of experimental bovine tropical theileriosis (Theileria annulata infection). Annales de Parasitologie Humaine et Comparee. 52: 597-608.

Hasanpour, A., Sabegh, Y.G. and Sadeghinasab, A. 2013. Assessment of serum antioxidant enzymes activity in cattle suffering from theileriosis. European J. of Exp. Bio. 3(1): 493-496.

Hussein, A.H., Mohammed, N.A.E.S. and Mohammed, H.K. 2007. Theileriosis and Babesiosis in cattle: Haemogram and some biochemical parameters. ISAH, Tartu, Estonia, pp. 143-150.

Khan, I.A., Khan, A., Hussein, A., Riaz, A. and Aziz, A. 2011. Haematobiochemical alterations in cross-bred cattle affected with bovine theileriosis in Semi-Arid Zone. Pak. Vet. J. 31(2): 137-140.

Kizil, O., Karapinar, T., Balikci, E. and Kizil, M. 2007. Tropikal tayleriyozisli sığırlarda hemogram ve bazı serum parametrelerindeki değişiklikler. Fırat Üniv. Sağ. Bil. Vet. Derg. 21: 011-014.

Kumar, S. 2012. Clinico-haematobiochemical and therapeutic studies on theileriosis in calves. M.V.Sc. Thesis. Department of Clinical Veterinary Medicine, Ethics and Jurisprudence, RAJUVAS, Bikaner.

Laiblin, C., Baysu, N. and Muller, M. 1978. Clinical study on experimental Theileria annulata infections of cattle. Berl. Munc. Tierar. Woch. 91: 25-27.

Modi, D.V., Bhadesiya, C.M. and Mandali, G.C. 2015. Haemato-biochemical Changes in Cross-bred Cattle Infected with Theileria annulata in Banaskantha District of Gujarat. Int. J. of Sci. and Res. Pub. 5(1): 1-4.

Omer, O.H., El-Malik, K.H., Magzoub, M., 
Mahmoud, O.M., Haroun, E.M., Hawas, A. and Omer, H. 2003. Biochemical profiles in Friesian cattle naturally infected with Theileria annulata in Saudi Arabia. Vet. Res. Commun. 27: 15-25.

Radostits, O.M., Gay, C.C., Hinchcliff, K.W. and Constable, P.D. 2007. Veterinary Medicine: A textbook of the diseases of cattle, horses, sheep, pigs and goats, tenth ed. Elsevier, Philadelphia.

Sandhu, G.S., Grewal, A.S., Singh, A., Kondal, J.K., Singh, J. and Brar, R.S. 1998. Haematological and biochemical studies on experimental Theileria annulata infection in cross-bred calves. Veterinary Research Communication. 22: 347-354.

Sharma, L.D., Sharma, N.N., Sabir, M. and Bhattacharyya, N.K. 1987. Clinicohaematological and biochemical changes in experimental Theileria infection in cross-bred calves. Ind. J. of
Vet. Med. 7: 154-156.

Singh, A., Singh, J., Grewal, A.S. and Brar, R.S. 2001. Study on some blood parameters of cross-bred calves with experimental Theileria annulata infections. Veterinary Research Communication. 25: 289-300.

Turgut, K. 2000. Veteriner Klinik Laboratuvar Teşhis. Genişletilmiş 2. Baskı. Bahçıvanlar Basım San., Konya, 496 pages.

Ugalmugle, S.S., Jayraw, A.K., Gatne and M.L. 2010. Prevalence and clinical pathology of bovine tropical theileriosis in cross-bred population of Ahmed nagar district of Maharashtra. J. of Vet. Parasitol. 24(2): 141-145.

Yadav, C.K. and Sharma, N.N. 1986. Changes in blood chemical components during experimentally induced Theileria annulata infections in cattle. Vet. Parasitol. 21: 91-98.

\section{How to cite this article:}

Pavan Goyal, Anju Chahar, R.K. Tanwar, Fakhruddin and Soni, S.S. 2018. Serum Biochemical Study to Cattle-calves naturally infected with Theileria annulata Confirmed by Nested Polymerase Chain Reaction in Bikaner District of Rajasthan. Int.J.Curr.Microbiol.App.Sci. 7(02): 2927-2932. doi: https://doi.org/10.20546/ijcmas.2018.702.355 